\title{
Effect of air exposure on the growth and distribution system in the colonial hydroid Dynamena pumila (L., 1758)
}

\begin{abstract}
V.S. Dementyev, N.N. Marfenin
Department of Invertebrate Zoology, Biological faculty, Lomonosov Moscow State University, Leninskie gory1/12,119234 Moscow,Russia.E-mails: demvitaly@mail.ru,marf47@mail.ru

ABSTRACT. The pulsation of the stolon coenosarc of the colonial hydroid Dynamena pumila (L., 1758) was recorded using time-lapse microvideo recording. The study included several experiments: control (without air exposure) and a series of consecutive air exposure periods: 5, 10, 20, $30 \mathrm{~min}$ and $1 \mathrm{~h}$. In general, comparison of the experiments with same colony in control and in a series of air exposure periods up to 30 min demonstrated no significant changes in the coenosarc pulsations and the hydroplasmic flow. Air exposure for 20 and 30 min caused a decrease in the amplitude of growth pulsations, and in growth increment by more than a third. The limit of permissible air exposure for $D$. pumila colonies is between 10 and $20 \mathrm{~min}$. Such a short air exposure period does not lead to disruption of the distribution system and the growth of the growing tips, and therefore can be used in laboratory studies of colonies. A longer air exposure period, namely one hour, is critical for the colony, since it leads to disruption of its structure integrity. Tissue degradation occurs, and the inner contents begin to pour out through the holes in the burst perisarc of the growing tip.

How to cite this article: Dementyev V.S., Marfenin N.N. 2021. Effect of air exposure on the growth and distribution system in the colonial hydroid Dynamena pumila (L., 1758) // Invert. Zool. Vol.18. No.2. P.69-79. doi: 10.15298/invertzool.18.2.01
\end{abstract}

KEY WORDS: safe duration time; tolerance; air exposure; colonial organism; Hydrozoa.

\section{Воздействие осушения на рост и распределительную систему колониального гидроида Dynamena pumila (L., 1758)}

\section{В.С. Дементьев, Н.Н. Марфенин}

Кафедра зоологии беспозвоночных, биологический факультет, МГУ имени М.В. Ломоносова, Ленинские горы 1/12, Москва, 119234,Россия.E-mails:demvitaly@mail.ru,marf47@mail.ru

РЕЗЮМЕ: Методом цейтраферной микровидеосъёмки проведена регистрация пульсаций ценосарка столона у колониального гидроида Dynamena pumila (L., 1758) в контроле (без осушения) и в ряду последовательных осушений: на 5, 10, 20, 30 мин и 1 ч. В целом не выявлено существенных изменений в пульсациях ценосарка и перемещении гидроплазмы при сравнении их на одной и той же колонии последовательно в контроле и в ряду осушений продолжительностью до 30 мин включительно. Осушение на 20 и 30 мин вызывает снижение амплитуды ростовых пульсаций, а прирост за один акт ростовой пульсации снижается более чем на треть. Таким 
образом, предел допустимого осушения колоний D.pumila находится между 10 и 20 мин. Такое непродолжительное осушение не приводит к нарушениям работы распределительной системы и роста верхушек, а значит - может применяться при проведении лабораторных исследований колоний. Более продолжительное осушение, а именно на 1 ч, становится критическим для колонии, поскольку приводит к нарушению целостности её структуры. Происходит деградация тканей, а сквозь отверстия в лопнувшем перисарке верхушки роста внутреннее содержимое начинает изливаться наружу.

Как цитировать эту статью: Dementyev V.S., Marfenin N.N. 2021. Effect of air exposure on the growth and distribution system in the colonial hydroid Dynamena pumila (L., 1758) // Invert. Zool. Vol.18. No.3. P.69-79. doi: 10.15298/invertzool.18.2.01

КЛЮЧЕВЫЕ СЛОВА: безопасная продолжительность осушения; устойчивость; осушение; колониальный организм; Hydrozoa.

\section{Introduction}

The duration of the air exposure phase in the intertidal zone is one of the main environmental factors that determines the composition of intertidal ecosystems and the vertical distribution of species (Stillman, Somero, 1996; Chappuis et al., 2014).

To date, the effects of air exposure on aquatic organisms have been studied fragmentarily and insufficiently. The research on algae response to air exposure is more comprehensive (Quadir et al., 1979; Taylor, Hay, 1984; Oates, 1985; Bell, 1993; Lipkin et al., 1993; Schagerl, Möstl, 2011). Fewer papers report on the subject of the reaction of aquatic invertebrates (mostly Gastropoda and Bivalvia) to air exposure, which can be assessed using different parameters: changes in growth rate (Sukhotin, Kulakowski, 1992; Sukhotin, Maximovich, 1994; Sukhotin et al., 2007), respiratory rate (McMahon, 1988), heart rate (Bjelde et al., 2015), and survival rate (Yin et al., 2017). The effect of air exposure on vital processes, in particular on growth and body pulsations, in hydroids has not previously been studied.

Our research was devoted to the study of the effect of air exposure duration on the growth and distribution (transport) system functioning. The aim of the study was to determine the effect of short-term air exposure of Dynamena pumila (L., 1758) hydroid colonies on growth pulsations, reflecting the growth rate of stolons of this species, and the functioning of the distribution system, and to test the possibility of using these characteristics as express indicators of hydroids' response to air exposure. We made an attempt to establish the tolerated period of air exposure for hydroids, within which all the main indicators of pulsations and growth (Marfenin, Dementyev, 2018) remain unchanged. Thus, we tested the assumption that short-term air exposure of $D$. pumila during laboratory experiments with them is acceptable.

\section{Materials and methods}

The object of study is the colonial hydroid Dynamena pumila (L., 1758) (Hydrozoa: Leptothecata: Sertulariidae), a typical representative of the lower intertidal zone biota of the White Sea.

Colonial hydroid D. pumila is an example of a modular organism in which hydrants are located on stems, and stems branch off from straight stolons at approximately equal distances; stems, in turn sometimes also branch (Marfenin, 1973). Side branches, which are arranged the same way as those from which they branch off, can form on the stems and the main stolon. Hydranths, together with the tubular coenosarc that connects them, form a single body of a branched modular organism (Fig. 1). All components of such an organism are interconnected not only physically, but also through the common gastrovascular cavity filled with hydroplasm. 


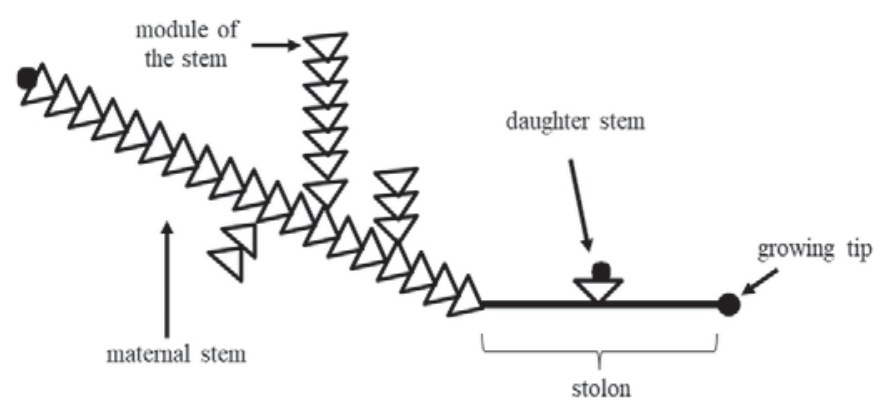

Fig. 1. Small colony of Dynamena pumila.

Рис. 1. Небольшая колония Dynamena pumila.

The wall of the tubular coenosarc consists of two cellular layers and a mesogleal basement membrane between them. The whole coenosarc surface is covered with a perisarc, forming a tube inside a tube. In certain places, the coenosarc adheres to the perisarc, for example, at the ends of stems and stolons, where they elongate as they grow. However, generally, there is a gap between the perisarc and coenosarc, which allows the coenosarc to pulsate.

The collection of hydroids, their cultivation and video recording of the distribution system functioning were carried out at the N.A. Pertsov White Sea Biological Station (WSBS) of the Biological Faculty of Lomonosov Moscow State University. Data processing was carried out according to the previously described method (Dementyev, Marfenin, 2019a, b; Marfenin, Dementyev, 2017, 2018, 2019a, b).

Colonies of hydroids were collected during low tide near the WSBS on the Eremeevsky rapid of the Velikaya Salma strait (Kandalaksha Bay, the White Sea). D. pumila is a rheophilic species that inhabits places with intense water exchange caused by tidal currents. The local population of $D$. pumila reaches its highest density at the Eremeevsky rapid, where the surface current velocity sometimes reaches $1 \mathrm{~m} / \mathrm{s}$.

In the laboratory, hydroids were grown on an artificial substrate (glass slides) in aquariums with circulating sea water at a constant temperature of $15 \pm 1.5^{\circ} \mathrm{C}$, roughly corresponding to the sea water temperature in the second half of summer. The intensive circulation of water in aquariums was achieved through aeration using microcompressors with porous diffusers.

Colonies were grown from fragments of individual stems from a stolon fragment according to the method described by Crowell (Crowell, 1957): a thread was wrapped around the glass slide several times and fragments (pieces of stems) were placed under the stretched thread with their cut planes facing the glass. In the process of reparative regeneration, the colony adhered to the glass at the cut point with chitin (with which the perisarc is formed) that was secreted at the growing tip. Subsequently, the fixing thread was removed. The hydroids were daily excessively fed with freshly hatched $\mathrm{Ar}$ temia salina (L., 1758) nauplii. Water in aquariums was changed once every three days.

For video recording, a glass slide with colonies was placed in a thermostatically controlled 0.251 cuvette with nonflowing water. Video recording was carried out using a microscope at $\times 100$ magnification and an Arecont-AV3100 camera with the image being recorded onto a computer. The temperature in each cuvette was maintained automatically at $15 \pm 1.5^{\circ} \mathrm{C}$. The duration of recording was at least 1 hour. Timelapse was set to 4 frames/ s. Video processing included measurement of the distance from the growing tip to the frame border, the coenosarc lumen width, and the distance of particle movements in the hydroplasm. It was carried out manually, as the automated software known to us is not accurate enough and has low resolution. 
Recorded indicators of living colonies can be divided into two groups: primary, which are obtained by direct measurement; and secondary, which can be derived from manipulations with primary indicators (Marfenin, Dementyev, 2017). Secondary indicators: the period and amplitude of pulsations of the stolon growing tip; the hourly stolon growth; the period and amplitude of transverse coenosarc pulsations; the period of unidirectional hydroplasmic flow (HF) rate pulsations; the maximum velocity of HFs to and from the stolon tip; the distance of particle transfer per act of unidirectional HF; the volume of displaced hydroplasm per HF; and the percentage of the rest ratio in coenosarc pulsations and hydroplasm movement.

Certain difficulties may arise in the determination of secondary parameters. While the interval between two maximal pulsations with a well-defined regular pattern is easy to determine, in the case of weakly pronounced regularity, its determination may depend on the researcher's subjective selection of the maxima. Sometimes an intermediate peak occurs between two maxima of regular pulsations for a very short time. In other cases, the maxima are several consecutive peaks. Such uncertainties in the manifestation of maxima affect the period value. In cases where the regularity of the pulsations is less pronounced, the period and amplitude values vary more, which is evident when they are averaged.

We investigated the parameters of growth and of the distribution system in the control (without air exposure) and in a series of experiments with consecutive air exposure periods: 5 , 10, 20, $30 \mathrm{~min}$ and 1 hour. For this purpose, unbranched rectilinear colonies with large parent stems were used, from which they were grown on glass, and small daughter stems, which only had a few pairs of hydrants. Air exposure was performed on a filter paper sheet at room temperature $\left(23^{\circ} \mathrm{C}\right)$ in the absence of direct illumination. After this, the glass with the colonies was returned to the cuvette with non-flowing water for the recording of the growth pulsations and transverse pulsations of the coenosarc stolon. In five such colonies, time-lapse micro video recording of the growing tips and the first stolon modules was carried out; in another ten only the growing tips in the control and after the 20- and/or 30-min air exposure periods were recorded; in another five - only the first stolon module in the control and after the 20- and/ or 30-min air exposure periods were recorded. The duration of most recordings was approximately 1.5-2 hours, however, after 30-min air exposure we recorded during the entire night (7-9 hours).

The statistical characteristics of the results presented in the article (arithmetic average value $\bar{x}$, standard error of the mean $\pm S E$ ) were calculated using Excel for all the experiments with a specific air exposure period together. The significance of the difference was determined using the Mann-Whitney U-test, as the subsets did not always correspond to the normal distribution.

\section{Results}

Comparison of the basic functioning parameters of the distribution (transport) system of the colonial hydroid $D$. pumila after different air exposure periods and without it revealed that the differences in the values of all studied parameters were very small.

The period of growth pulsations $\left(\mathrm{P}_{\mathrm{GP}}\right)$ was $12.7 \pm 1.2$ min (sampling: $\mathrm{n}=73$ ) in the control and increased to $14.1 \pm 1.9 \mathrm{~min}(\mathrm{n}=115)$ after a 30-min period of air exposure (Table 1). However, these values did not differ significantly $(p>0.05)$ both when comparing between adjacent periods (control and 5 min air exposure; air exposure for 5 and $10 \mathrm{~min}$, etc.), and between the continuous periods of air exposure (20 and $30 \mathrm{~min}$ ) and control.

The amplitude of growth pulsations $\left(\mathrm{A}_{\mathrm{GP}}\right)$ was $26.9 \pm 1.7 \mu \mathrm{m}(\mathrm{n}=71)$ in the control and changed non-linearly with an increasing of the air exposure period duration: decreased after five- and twenty-minute periods and increased after ten and thirty minutes (Table 1).

Despite the fact that air exposure has almost no effect on the period and amplitude of growth pulsations, it leads to a disturbance in the growth dynamics. Under the influence of air exposure, 
Table 1. Parameters of growth pulsations in the control and after different periods of air exposure.

Таблица 1. Параметры ростовых пульсаций в контроле и при разных продолжительностях осушения.

\begin{tabular}{|c|c|c|c|c|c|c|c|c|c|c|c|}
\hline \multirow{2}{*}{ 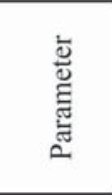 } & \multirow{2}{*}{ 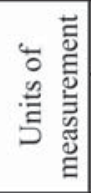 } & \multicolumn{2}{|c|}{$\begin{array}{c}\text { Without air } \\
\text { exposure }\end{array}$} & \multicolumn{2}{|c|}{$\begin{array}{l}\text { Air exposure } \\
\text { for } 5 \mathrm{~min}\end{array}$} & \multicolumn{2}{|c|}{$\begin{array}{c}\text { Air exposure } \\
\text { for } 10 \mathrm{~min} \\
\end{array}$} & \multicolumn{2}{|c|}{$\begin{array}{l}\text { Air exposure } \\
\text { for } 20 \mathrm{~min}\end{array}$} & \multicolumn{2}{|c|}{$\begin{array}{l}\text { Air exposure } \\
\text { for } 30 \mathrm{~min}\end{array}$} \\
\hline & & $\overline{x \pm S E}$ & $n$ & $\bar{x} \pm S E$ & $n$ & $\bar{x} \pm S E$ & $n$ & $\bar{x} \pm S E$ & $n$ & $\bar{x} \pm S E$ & $n$ \\
\hline $\mathrm{P}_{\mathrm{GP}}$ & $\min$ & $12.7 \pm 1.2$ & 73 & $13.2 \pm 0.5$ & 48 & $12.7 \pm 0.6$ & 82 & $14.3 \pm 1.5$ & 51 & $14.1 \pm 1.9$ & 115 \\
\hline $\mathrm{A}_{\mathrm{GP}}$ & $\mu \mathrm{m}$ & $26.9 \pm 1.7$ & 71 & $21.5 \pm 1.6$ & 43 & $27.5 \pm 2.0$ & 80 & $9.3 \pm 0.7$ & 47 & $16.3 \pm 0.9$ & 130 \\
\hline $\mathrm{M}_{\mathrm{GP}}$ & $\mu \mathrm{m} / \mathrm{h}$ & $45.4 \pm 10.0$ & 15 & $49.6 \pm 9.0$ & 7 & $39.8 \pm 7.3$ & 9 & $27.8 \pm 6.0$ & 9 & $5.5 \pm 7.5$ & 9 \\
\hline $\mathrm{m}_{\mathrm{gp}}$ & $\mu \mathrm{m}$ & $12.1 \pm 1.0$ & 56 & $11.8 \pm 0.9$ & 36 & $13.8 \pm 0.9$ & 69 & $7.4 \pm 0.8$ & 38 & $3.7 \pm 0.7$ & 121 \\
\hline$(+) \mathrm{GP}_{\%}$ & $\%$ & \multicolumn{2}{|l|}{8.1} & \multicolumn{2}{|l|}{8.2} & \multicolumn{2}{|l|}{6.8} & \multicolumn{2}{|l|}{3.9} & \multicolumn{2}{|l|}{3.1} \\
\hline$(-) \mathrm{GP}_{\%}$ & $\%$ & \multicolumn{2}{|l|}{4.4} & \multicolumn{2}{|l|}{4.6} & \multicolumn{2}{|l|}{3.7} & \multicolumn{2}{|l|}{1.7} & \multicolumn{2}{|l|}{2.5} \\
\hline (0)GP\% & $\%$ & \multicolumn{2}{|l|}{87.5} & \multicolumn{2}{|l|}{87.2} & \multicolumn{2}{|l|}{89.4} & \multicolumn{2}{|l|}{94.4} & \multicolumn{2}{|c|}{94.4} \\
\hline
\end{tabular}

Abbreviations: $\mathrm{P}_{\mathrm{GP}}$ - period of growth pulsations; $\mathrm{A}_{\mathrm{GP}}$ - amplitude of growth pulsations; $\mathrm{M}_{\mathrm{GP}}$ - growth per hour; $\mathrm{m}_{\mathrm{gp}}$ - growth per one cycle of growth pulsations; $(+) \mathrm{GP}_{\%}$ - percentage of positive $\Delta \mathrm{GP}$ (or "expansion ratio"); (-)GP $\%$ - percentage of negative $\Delta \mathrm{GP}$ (or "contraction ratio"); (0)GP $\%$ - percentage of "zero" $\Delta \mathrm{GP}$ (or "rest ratio").

the contraction phase and the so-called retraction (Wyttenbach, 1968) of the tip after its protrusion gradually disappeared, and the pulsation curve became more stepped with a smaller increase during one act of pulsation (Fig. 2).

Growth per one cycle of growth pulsations $\left(\mathrm{m}_{\mathrm{gp}}\right)$ was $12.1 \pm 1.0 \mu \mathrm{m}(\mathrm{n}=56)$ in the control, and significantly decreased $(\mathrm{p}<0.01)$ after 20 $\min$ period of air exposure to $7.4 \pm 0.8 \mu \mathrm{m}(\mathrm{n}=$
38), and after 30 -min period - to $3.7 \pm 0.7 \mu \mathrm{m}$ $(\mathrm{n}=121)$. However, after five- and ten-minute periods, it did not significantly differ from the control values $(p>0.05)$ (Table 1).

Growth per hour $\left(\mathrm{M}_{\mathrm{GP}}\right)$ decreased with increasing of the air exposure time to 20 and 30 min (Table 1) with a high degree of confidence $(p<0.01)$. As this indicator is accumulative, i.e. combines intermediate growth increments dur-

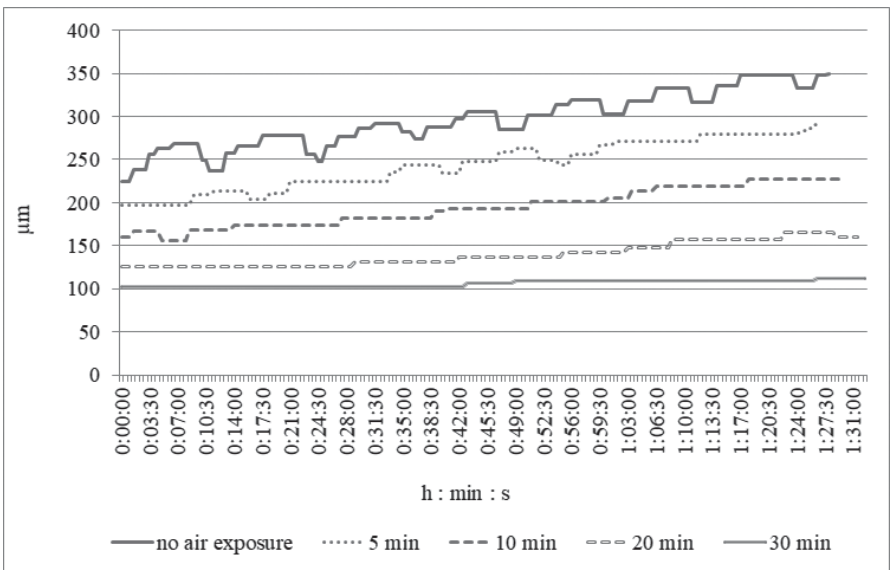

Fig. 2. The dynamics of growth pulsations of the stolon tip of the colony No. D.p.8-1 (2017) in the control and after air exposure. The temperature was $15 \pm 1.5^{\circ} \mathrm{C}$.

Рис 2. Динамика ростовых пульсаций верхушки столона колонии № D.p.8-1 (2017) в контроле и последовательном ряду осушений. Температура: $15 \pm 1.5^{\circ} \mathrm{C}$. 


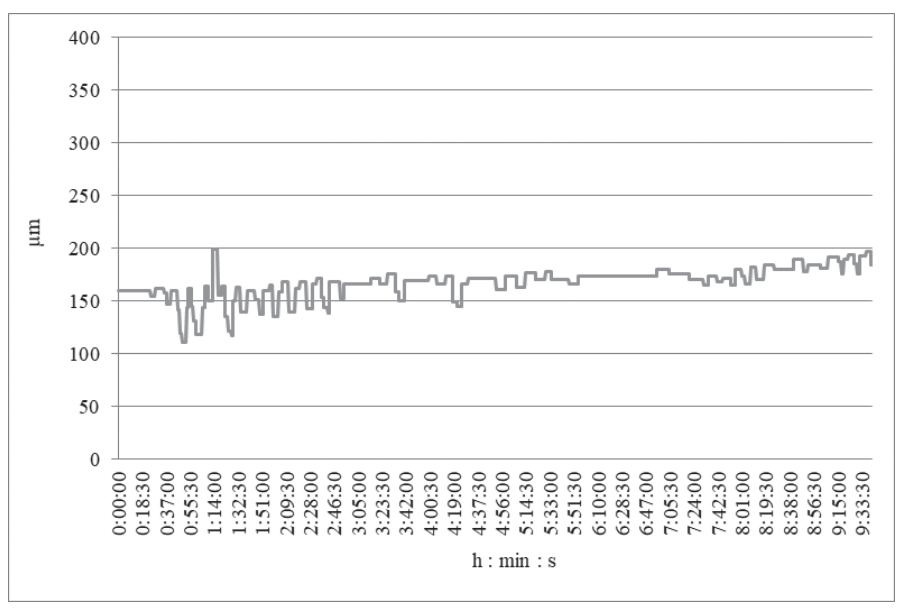

Fig. 3. The dynamics of the growth pulsations of the stolon tip of the colony No. D.p.10-3 (2017) after a 30min air exposure period, recorded for an entire night (ep. 268/2017, $15.6{ }^{\circ} \mathrm{C}$ ).

Рис. 3. Динамика ростовых пульсаций верхушки столона колонии № D.p.10-3 (2017) после 30минутного осушения, отснятая в течение ночи (эп. $268 / 2017,15.6^{\circ} \mathrm{C}$ ).

ing a single pulsation act, it can be expected that it reflects the reaction of growth pulsations better than each pulsation separately. However, significantly larger samples were used in the comparison of growth increments with average growth pulsations than in comparison of growth increments per hour. As a result, the averaged data for individual growth pulsations was more accurate than the averaged data for the growth per hour, shown by the standard errors of the mean (Table 1). Based on these indicators, a significant reduction in the growth of stolons occurred with an increasing of the duration of air exposure from 10 to $20 \mathrm{~min}$, and further to $30 \mathrm{~min}$.

Nevertheless, a disturbance in the dynamics of growth pulsations during a 30-min air exposure period did not always occur. Three of the nine colonies exposed to air for $30 \mathrm{~min}$ were recorded throughout the night to determine the possibility of restoration of the normal growth pulsations (GP) rhythm after relatively long stress. These colonies retained more or less rhythmic, however, sometimes fading GPs. At the same time, their growth increment became insignificant, i.e. recovery of growth did not occur in 7-9 h (Fig. 3). The remaining colonies, which were tracked for $1.5-2 \mathrm{~h}$ after a $30-\mathrm{min}$ air exposure period, demonstrated a weak stepped nature of the stolon growth pulsations.

Air exposure had an effect on lateral pulsation parameters.

With an increasing in the air exposure duration, the period of lateral (transversal) pulsations $\left(\mathrm{P}_{\text {trp }}\right)$ of the stolon gradually and slightly decreased from $17.3 \pm 1.9 \mathrm{~min}$ in control to $13.7 \pm$ $1.3 \mathrm{~min}$ after 30 -min air exposure period, but no significant differences were found $(p>0.05)$.

At the same time, the amplitude of the lateral pulsations $\left(A_{\operatorname{trp} D}\right)$ decreased from $19.5 \pm 1.3 \mu \mathrm{m}$ $(n=54)$ in the control to $14.6 \pm 0.6 \mu \mathrm{m}(\mathrm{n}=170)$ after $30 \mathrm{~min}$ of air exposure $(\mathrm{p}<0.05)$. The decrease in amplitude was most significant with an increasing in air exposure time from 20 to $30 \mathrm{~min}$. Similar results were obtained for the second of the two coenosarc cross sections recorded in the frame.

The proportion of rest in the dynamics of pulsations of the stolon coenosarc did not depend on the duration of air exposure and was more than $80 \%$.

The period of hydroplasmic flows (HF) $\mathrm{P}_{\mathrm{HF}}$ slightly decreased after air exposure, but the differences were significant $(\mathrm{p}<0.01)$ only for 20 -min $(11.4 \pm 0.6 \mathrm{~min})$ and 30 -min exposure periods $(12.7 \pm 0.3 \mathrm{~min})$. 


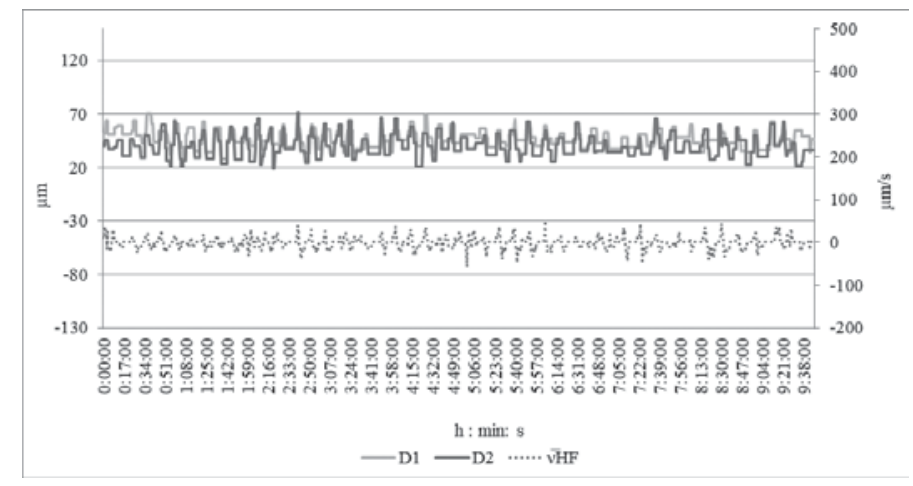

Fig. 4. The dynamics of the lateral pulsations and HFs in the first stolon module of the colony No. D.p.43 (2017) after a 30-min air exposure period, recorded for an entire night (ep. 238/2017, $14.6{ }^{\circ} \mathrm{C}$ ).

Abbreviations: D1 and D2 - coenosarc lumen diameters $(\mu \mathrm{m})$ in the optical plane parallel to the substratum in two coenosarc cross sections within the field of vision of one internode (cross section D1 is further from the stolon tip than D2); $v \overline{\mathrm{H}} \mathrm{F}$ - hydroplasmic flow rate $(\mu \mathrm{m} / \mathrm{h})$ - the distance that identifiable particles in stolon cavity cover per $1 \mathrm{~s}$. Рис. 4. Динамика латеральных пульсаций и ГПТ в первом модуле столона колонии № D.p.4-3 (2017) после 30-минутного осушения, отснятая в течение ночи (эп. 238/2017, $14.6{ }^{\circ} \mathrm{C}$ ).

Обозначения: D1 и D2 - величины просвета ценосарка (мкм) в оптической плоскости, параллельной субстрату в двух сечениях ценосарка в пределах поля зрения одного междоузлия (сечение D1 дальше от верхушки столона, чем D2); $v \overline{\mathrm{H}} \mathrm{F}$ - скорость гидроплазматического течения (мкм/с), т.е. дистанция, которую проходят распознаваемые частицы в полости столона за $1 \mathrm{c}$.

The HF rate (HF amplitude), both the magistral $\mathrm{A}_{(+) \mathrm{HF}}$ and compensatory $\mathrm{A}_{(-) \mathrm{HF}}$, rised with an increasing in the air exposure duration, however, there were significant differences only between control $(23.3 \pm 1.6 \mu \mathrm{m} / \mathrm{s})$ and 30-min exposure $(30.5 \pm 1.7 \mu \mathrm{m} / \mathrm{s})$.

The distance of the flows and the volume of the transferred hydroplasm did not depend on the duration of the air exposure.

The proportion of rest in HF was 59.9\% in control. It decreased at first, reaching a minimum after 10-min air exposure period (41.6\%), and then increased after $20-\min (54.2 \%)$ and 30 -min periods $(68.9 \%)$.

In general, air exposure for half an hour lead to a significant decrease in the growth gain of the stolon tip after 20-min exposure compared with the control, although it does not significantly depress HFs and lateral pulsations (Fig. 4).

After an hour-long air exposure, we observed specific changes in the tip and module of the stolon. The colony sustained damage after being returned to water following an hour-long exposure. Several minutes after returning to water the perisarc of the apical part of the tip burst, and coenosarc cell aggregates began to flow out through the newly formed hole (Fig. 5). At the same time there were no pulsations or growth. Four out of five tips exposed to air for one hour demonstrated such changes. The tip of the other colony, upon returning to water, managed to perform one pulsation along the stolon axis, after which it stopped. The coenosarc of the stolon's first module also stopped rhythmically pulsing after an hour-long air exposure. The lumen diameter of the gastrovascular cavity became indistinguishable; it seemed as if it was filled with soft tissues of the coenosarc. However, the remnants of the tissues continued to move inside the perisarc, mostly randomly (Fig. 6). In one of the studied colonies, the resulting cell mass moved directly towards the growing tip. It apparently continued to flow out from the deformed perisarc of the apical part of the tip. HFs stopped. As the colonies were only recorded for 1.5-2 hours after an hour-long air exposure, we could not point out the moment when the degradation stopped and the regeneration of the terminal part of the stolon began. 


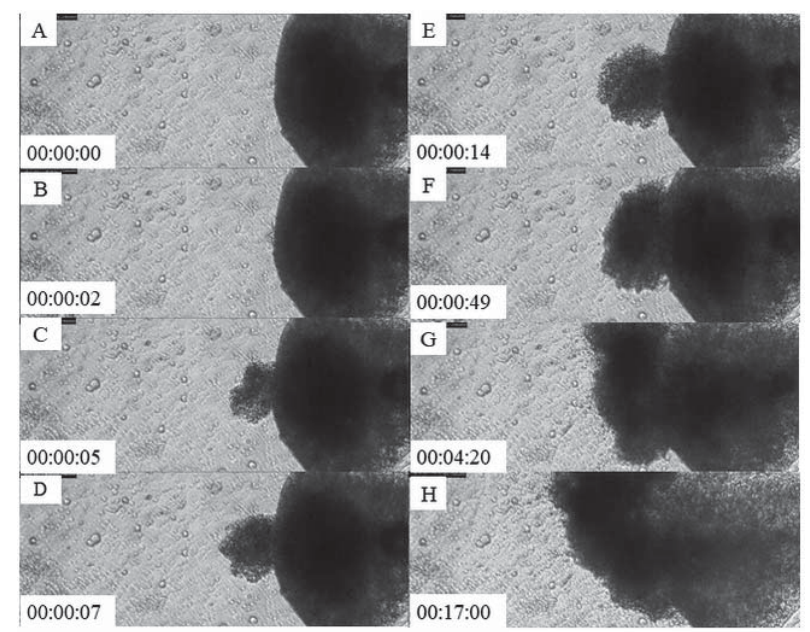

$100 \mu \mathrm{m}$

Fig. 5. Consecutive stages $(\mathrm{a}-\mathrm{h})$ of Dynamena pumila stolon tip degradation following the return of the colony to saline water after an hour-long period of air exposure. Time format: h: min : s.

Рис. 5. Последовательные стадии $(\mathrm{a}-\mathrm{h})$ деградации верхушки столона Dynamena pumila при возвращении колонии в морскую воду после часового осушения. Формат времени: ч : мин : c.
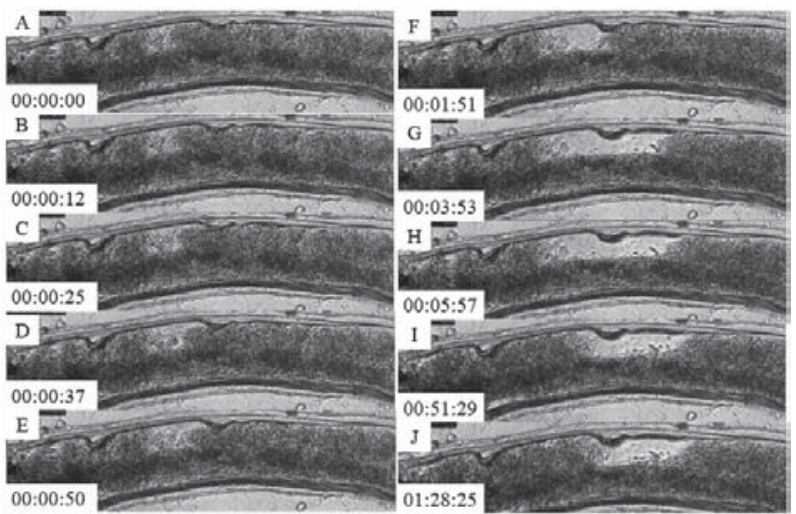

$\underline{100 \mu \mathrm{m}}$

Fig. 6. Consecutive stages (a-j) of Dynamena pumila first stolon module degradation after an hour-long period of air exposure. Time format: $\mathrm{h}: \min : \mathrm{s}$.

Рис. 6. Последовательные стадии (a-j) деградации ценосарка первого модуля столона Dynamena pumila после часового осушения. Формат времени: ч : мин : с.

\section{Discussion}

In this study, we compared the vital functions of a colonial hydroid after different periods of air exposure for several primary and multiple derivative quantitative indicators ("secondary" indicators, see: Dementyev, Marfenin, 2019a, b; Marfenin, Dementyev, 2017, 2018, 2019a, b). All of them together characterize three main processes: 1) growth, 2) pulsations of the coenosarc, and 3) movement of the hydroplasm in the stolon.

In general, short-term air exposure (up to 20 min) did not lead to any noticeable disruptions in the distribution system. We did not detect any significant changes in the coenosarc pulsations and the hydroplasm movement of the same colony between the control and the consecutive series of air exposure periods. Only after 20and 30-min long exposure did changes in growth 
manifest themselves, namely: reduction of growth increment, both during a separate pulsation act and per hour.

A longer (hour-long) air exposure period was critical for the colony — it lead to a disruption in its structure integrity. Tissue degradation occurred, and inner contents began to flow out through the holes in the burst perisarc of the growing tip.

D. pumila is a characteristic intertidal form living in great abundances on the underside of stones and algae on the foreshores (Naumov, 1969). Colonies of D. pumila are well adapted to life in the lower intertidal zone. This species tolerates freezing, draining and temperature fluctuations associated with it (Marfenin, 1971). D. pumila has similar adaptations to air exposure as the previously described Laomedea flexuosa Alder, 1857 from the same biotope (Marfenin, Belorustseva, 2008). Relatively short weakly branched stems with short internodes and compactly arranged hydrants make it possible to form dense thickets, which retain moisture, preventing colonies from desiccation. A thick perisarc gives stems the ability to resist the water surface tension during air exposure.

The absence of visible disturbances in the work of the distribution system after air exposure, apparently, is also an adaptation to life in such an unstable biotope as the intertidal zone. Air exposure that occurs twice a day is not a critical factor in the life of the hydroid and does not affect the implementation of the vital function of transporting food through the colony (Marfenin, Dementyev, 2020a, b).

In hydroids, growth is the first vital function that is affected by adverse environmental conditions. It has been previously shown that after thirty hours in laboratory conditions (at room temperature and with water changes) the number of growing tips sharply decreases (Marfenin, 1973). In the absence of water exchange, when the colony is in a non-flowing cuvette, the period of growth pulsations is reduced by $20 \%$, while significant changes in coenosarc pulsations and hydroplasm movement do not occur (Marfenin, Dementyev, 2019b).

The data from this study confirms the vulnerability of growth of the colony to external factors. After air exposure for 20 and $30 \mathrm{~min}$, the stolon growing tips were the first to react: their amplitude and period of pulsations slowed down. The reaction of the distribution system to air exposure was to reduce the $\mathrm{P}_{\text {trp }}$ and $\mathrm{P}_{\mathrm{HF}}$ periods. However, the observed tendency of pulsation period changes during air exposure is not significant due to high variability, despite the large sampling size. Therefore, air exposure period of up to $30 \mathrm{~min}$ has practically no effect on lateral pulsations and HF. Reduction of growth rate is significant. Twenty-minute air exposure lead to a decrease in growth rate during one act of growth pulsation by more than one third, and 30-min air exposure lead to a further twofold decrease (Table 1). We found that, even after being taken out of the water for at least $20 \mathrm{~min}$, hydroids were able to function the same way as if they were in water. This inertia in the reaction of colonial hydroids to air exposure is very important for understanding that short-term air exposure during ordinary low tides in the lower intertidal zone does not lead to an interruption of stolon growth and stems and the functioning of the distribution system. The duration of inertia should be considered during the design of experimental studies using hydroids.

The aim of our work did not include the study of the adaptations of colonies to air exposure and most of our recordings are relatively short (approximately 1.5 hours). However, the video clips that we recorded after 30-min air exposure of the colonies during the night are 79 hours long, and they show no evidence of any noticeable changes in the dynamics of the distribution system during the specified period of time (Fig. 4). Neither the parameters of the lateral pulsations (period, amplitude), nor the parameters of the hydroplasmic flows (frequency and HF rate, the distance of particle transport, volume of hydroplasm) changed significantly. The stability of the gastrovascular system is crucial for the survival of the colony for long periods of time.

Hydroids, characterized by modular organization and simplicity of structure, respond to air exposure in two ways. Exposure for a short period (up to $30 \mathrm{~min}$ ) does not explicitly affect 
the operation of the distribution system, but leads to a slowdown in growth. However, a longer period of time (one hour) without water initiates catastrophic processes of the degradation of soft tissues in the colonies. But minimal period of air exposure at low tides lasts more than an hour even at the lower horizon of the littoral zone. Thus, D. pumila can be considered weakly tolerant organism in regard to air exposure compared to other aquatic invertebrates. Therefore, there are no colonies on the rocks above low tide.

We understand that the conditions we have created for air exposure (complete dehydration of glass with colonies at room temperature) is hardly found in the habitat natural to hydroids. At the moment of low tide, the hydroids on the intertidal zone are not completely dried out, but are covered with thalli of macrophyte algae, on which they grow. Here, moisture is preserved, and the colonies themselves are wet to the touch. However, the aim of our work was to determine the critical duration of air exposure - time period sufficient to trigger the occurrence of disturbances in the growth and distribution system functioning. This threshold, according to our data, is air exposure for a period of 30 to 60 min, after which the integrity disruption of the tissues in the colony may be observed.

Thus, this species withstands only a very limited drying time. The limit of permissible air exposure of $D$. pumila colonies, determined using physiological indicators, is between 10 and $20 \mathrm{~min}$. Such a short exposure time does not lead to disruption of the distribution system functioning and the growth of the tips, and therefore can be used in laboratory studies of colonies.

Conflict of interest. The authors declare that they have no conflict of interest.

Support: The research was carried out as part of the Scientific Project of the State Order of the Government of Russian Federation to Lomonosov Moscow State University No. AAAA-A16-116021660060-5.

\section{References}

Bell E.C. 1993. Photosynthetic response to temperature and desiccation of the intertidal alga Mastocarpus papillatus // Marine Biology. Vol.117. P.337-346.

Bjelde B.E., Miller N.A., Stillman J.H., Todgham A.E. 2015. The role of oxygen in determining upper thermal limits in Lottia digitalis under air exposure and submersion // Physiological and Biochemical Zoology. Vol.88. No.5. P.483-493.

Chappuis E., Terradas M., Cefalì M.E., Mariani S., Ballesteros E. 2014. Vertical zonation is the main distribution pattern of littoral assemblages on rocky shores at a regional scale. Estuarine // Coastal and Shelf Science. Vol.147. P.113-122.

Crowell S. 1957. Differential responses of growth zones to nutritive level, age, and temperature in the colonial hydroid Campanularia // Journal of Experimental Zoology. Vol.134. P.63-90.

Dementyev V.S., Marfenin N.N. 2019a. The effect of desalination on the growth, coenosarcs pulsations, and hydroplasm movement in the colonial hydroid Dynamena pumila (L., 1758) // Biology Bulletin Reviews. Vol.9. No.3. P.250-266. doi: 10.1134/ S2079086419030022.

Dementyev V.S., Marfenin N.N. 2019b. Influence of temperature on the growth, coenosarc pulsations, and hydroplasm movement in the colonial hydroid Dynamena pumila (L., 1758) // Biology Bulletin Reviews. Vol.9. No.5. P.432-452. doi: 10.1134/ S2079086419050037.

Lipkin Y., Beer S., Eshel A. 1993. The ability of Porphyra linearis (Rhodophyta) to tolerate prolonged periods of desiccation // Botanica Marina. Vol.36. P.517-523.

Marfenin N.N. 1971. [Colonial integration in the hydroid Dynamena pumila (Hydrozoa, Leptolida). Colonial reaction to winter freezing] // Doklady Akademii Nauk SSSR. Vol.199. P.489-492 [in Russian].

Marfenin N.N. 1973. [Growth morphology of the colony in hydroid polyp Dynamena pumila (Hydrozoa, Leptolida)] // Zhurnal Obshchey Biologii. Vol.34. P.727737 [in Russian].

Marfenin N.N., Belorustseva S.A. 2008. How the distribution of hydroid colonies of Laomedea flexuosa is limited to a narrow belt along the lower littoral zone // Journal of the Marine Biology Association of the United Kingdom. Vol.88. P.1559-1566.

Marfenin N.N., Dementyev V.S. 2017. Functional morphology of hydrozoan stolons: stolonal growth, contractility, and hydroplasmic movement in Gonothyraea loveni (Allman, 1859) // Marine Biology Research. Vol.13. No.5. P.521-537. doi: 10.1080/17451000. 2016.1276292.

Marfenin N.N., Dementyev V.S. 2018. Paradox of extended flows in Dynamena pumila (Linnaeus, 1758) colonial hydroid // Biology Bulletin Reviews. Vol.8. No.3. P.212-226. doi: 10.1134/S2079086418030088.

Marfenin N.N., Dementyev V.S. 2019a. Longitudinal stolon pulsations in the colonial hydroid Dynamena 
pumila (Linnaeus, 1758) // Biology Bulletin Reviews. Vol.9. No.1. P.42-51. doi: 10.1134/ S2079086419010043.

Marfenin N.N., Dementyev V.S. 2019b. Growth, coenosarc pulsations, and hydroplasm movement in the colonial hydroid Dynamena pumila (L., 1758) placed in flow-through and nonflow cuvettes // Biology Bulletin Reviews. Vol.9. No.1. P.52-61. doi: 10.1134/ S2079086419010055.

Marfenin N.N., Dementyev V.S. 2020a. On the question of the length of hydroplasma flows in the colonial hydroid Dynamena pumila (L., 1758) // Biology Bulletin Reviews. Vol.10. No.5. P.441-455. doi: 10.1134/ S2079086420050047.

Marfenin N.N., Dementyev V.S. 2020b. [Stems as a generators of the hydroplasmic currents in Dynamena pumila (L., 1758) colonial hydroid] // Zhurnal Obshchey Biologii. Vol.81. No.6. P.421-443 [in Russian]. doi: $10.31857 / \mathrm{S} 0044459620060032$

McMahon R.F. 1988. Respiratory response to periodic emergence in intertidal mollusks // American Zoology. Vol.28. P.97-114.

Naumov D.V. 1969. Hydroids and hydromedusae of the U.S.S.R (Keys to the fauna of the USSR). Jerusalem. Israel Program for Scientific Translations. $660 \mathrm{p}$.

Oates B.R. 1985. Photosynthesis and amelioration of desiccation in the intertidal saccate alga Colpomenia peregrina // Marine Biology. Vol.89. P.109-119.

Quadir A., Harrison P.J., DeWreede R.E. 1979. The effects of emergence and submergence on the photosynthesis and respiration of marine macrophytes // Phycologia. Vol.18. No.1. P.83-88.

Stillman J.H., Somero G.N. 1996. Adaptation to temperature stress and aerial exposure in congeneric species of intertidal porcelain crabs (genus Petrolisthes): Correlation of physiology, biochemistry and morphology with vertical distribution // Journal of Experimental Biology. Vol.199. P.1845-1855.

Sukhotin A.A., Kulakowski E.E. 1992. Growth and population dynamics in mussels (Mytilus edulis L.) cultured in the White Sea // Aquaculture. Vol.101. P.5973.

Sukhotin A.A., Maximovich N.V. 1994. Variability of growth rate in Mytilus edulis L. from the Chupa Inlet (the White Sea) // Journal of Experimental Marine Biology and Ecology. Vol.176. P.15-26.

Sukhotin A.A., Strelkov P.P., Maximovich N.V., Hummel H. 2007. Growth and longevity of Mytilus edulis (L.) from northeast Europe // Marine Biology Research. Vol.3. P.155-167.

Taylor P.R., Hay M.E. 1984. Functional morphology of intertidal seaweeds: adaptive significance of aggregate vs. solitary forms // Marine Ecology Progress Series. Vol.18. P.295-302.

Wyttenbach C.R. 1968. The dynamics of stolon elongation in the hydroid, Campanularia flexuosa // Journal of Experimental Zoology. Vol.167. No.3. P.333-352.

Responsible editor V.V. Malakhov 